\title{
CONCEPTIONS OF SEXUALITY OF ADOLESCENTS LIVING IN RESIDENCE CARES: ARE THEIR INTERESTS AND CURIOSITIES DIFFERENT?
}

\author{
Zélia Caçador Anastácio \\ CIEC, Instituto de Educação, Universidade do Minho \\ Braga, Portugal \\ zeliaf@ie.uminho.pt
}

Recepción Artículo: 27 octubre 2021 Admisión Evaluación: 27 octubre 2021 Informe Evaluador 1: 28 octubre 2021 Informe Evaluador 2: 29 octubre 2021 Aprobación Publicación: 30 octubre 2021

\section{ABSTRACT}

The institutionalization of children and adolescents generally is due to unfavourable socio-economic conditions, children maltreatment, school absenteeism and adolescents' behavioural problems, including sexual risk behaviours. Sexuality education (SE) is very difficult to approach in residence care, given the sensitive and problematic life stories of adolescents involved. It is important to know what adolescents already know and what they want to learn and clarify about sexuality. The research question was: What interests and curiosities of sexuality do adolescents living in residence care have? The objectives were to make a diagnosis of adolescents' interests, needs and conceptions about sexuality and to relate these conceptions with individual factors. A transversal study was done following a quantitative methodology. A questionnaire was carried out for this research. Dependent variables were: sources of information about SE; perceptions about the role of SE on children and adolescents' development; responsible intervener for SE; sexuality topics about which adolescents want to learn more. A conve-

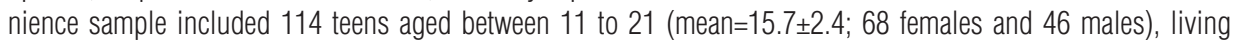
$60,5 \%$ of them since more than 24 months ago in residence care. A statistical analysis was done. Results showed that in adolescents' views, the main role of SE is: to help them to respect different sexual orientations; to understand that sexuality expresses differently along the lifespan; and to promote equal rights and opportunities between men and women. Their main sources of information are friends, internet and familiars with approximately equal age. Persons they consider to be most responsible for their SE are doctors, nurses and mothers, with significant differences for health professionals, girls having a higher preference for them than boys. Topics about which adolescents have more interest and curiosity are: love, friendship and romantic relationships; adolescence; diversity, tolerance, sexual orientation and respect; and sexually transmitted diseases and infections.

Keywords: adolescents; residence care; sexuality conceptions and interests 


\section{CONCEPTIONS OF SEXUALITY OF ADOLESCENTS LIVING IN RESIDENCE CARES: ARE THEIR INTERESTS AND CURIOSITIES DIFFERENT?}

\section{RESUMO}

Conceções sobre sexualidade de adolescentes que vivem em instituições de acolhimento: serão os seus interesses e curiosidades diferentes?. A institucionalização de crianças e adolescentes geralmente é devida a condições socioeconómicas desfavoráveis, maus-tratos a crianças, absentismo escolar e problemas comportamentais dos adolescentes, incluindo comportamentos sexuais de risco. A educação sexual (ES) é muito difícil de abordar em instituições de acolhimento, dadas as histórias de vida sensíveis e problemáticas dos adolescentes envolvidos. É importante conhecer o que os adolescentes já sabem e o que querem aprender e esclarecer sobre a sexualidade. A questão da investigação foi: Que interesses e curiosidades sobre sexualidade têm os adolescentes que vivem em lares de acolhimento? Os objetivos foram diagnosticar os interesses, necessidades e concepções dos adolescentes sobre a sexualidade e relacionar essas concepções com factores individuais. Realizou-se um estudo transversal, seguindo uma metodologia quantitativa. Foi construído um questionário específicamente para esta investigação. As variáveis dependentes foram: fontes de informação sobre ES; percepções sobre o papel da ES no desenvolvimento das crianças e adolescentes; interveniente responsável pela ES; temas de sexualidade sobre os quais os adolescentes querem aprender mais. A amostra foi de conveniencia

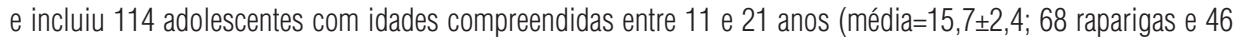
rapazes), vivendo 60,5\% deles desde há mais de 24 meses em acolhimento institucional. Efetuou-se uma análise estatística. Os resultados mostraram que na opinião dos adolescentes, o principal papel da ES é: ajudá-Ios a respeitar as diferentes orientações sexuais, a compreender que a sexualidade se expressa de forma diferente ao Iongo da vida; e promover a igualdade de direitos e oportunidades entre homens e mulheres. As suas principais fontes de informação são os amigos, a Internet e os familiares com idades próximas. As pessoas que eles mais consideram responsáveis pela sua ES são médicos, enfermeiros e mães, com diferenças significativas para médi$\cos$, tendo as raparigas maior preferência por eles do que os rapazes. Os tópicos sobre os quais os adolescentes têm mais interesse e curiosidade são: amor, amizade e namoro; adolescência; diversidade, tolerância, orientação sexual e respeito; e doenças e infeções sexualmente transmissíveis.

Palavras chave: adolescentes; instituições de acolhimento; conceções e interesses de sexualidade

\section{INTRODUCTION}

The institutionalization of children and adolescents reflects a big problem in our society. To the unfavourable socio-economic conditions have been added the maltreatment, school absenteeism and behavioural problems, including sexual risk behaviours. According to the CASA Report 2019, the majority of the individuals in residence care are boys (53\%), adolescents, being $68,2 \%$ of them aged between 12 and 20 years old, with the group of 15 17 registering $36,1 \%$ and being now the more increasing age group. The main reasons for institutionalization are problematic behaviours, followed by mental health problems, but suspicions of prostitution and sexual abuse are also mentioned in the report (Macedo, Silva \& Banhudo, 2020). The largest age groups correspond to the early and middle adolescence, when the body changes and the sexual desire arouses (Christie \& Viner, 2005).

Residential care is conceived by the Portuguese Decree Law n. $.164 / 2019$ "as a measure whose execution aims at the provision of care and an adequate satisfaction of the physical, psychological, emotional and social needs of children and young people, favouring their integration in a safe social and family context, promoting their education, well-being and integral development" (PORTUGAL, DRE, 2019, p. 65, Author translation).

Although they are living in residence care, children and adolescents are still vulnerable to risky sexual behaviors, since they have no family support and in many cases, before institutionalization, they have been subjected to traumatic sexual experiences that may have led them to develop early sexuality or to trivialize sexual behaviors, exposing themselves to risks for their health and to their peers. The knowledge acquired about these adolescents' sexual behaviors was obtained in several meetings between the researcher and caregivers of the institutions, when they asked for assistance to deal with some teens, in consequence of their sexual attitudes and behaviors or when professionals were afraid about a new teen coming to the residence care (due to the previous analyze of the report containing him/her life history). Behaviors like exhibitionism in front of caregivers, multiplicity of sexual partners, 
sexual exploitation and abuse between teens living in the same residence care, were some of the problematic sexual behaviors that professionals have faced, which motivated them to claim for help.

Many adults consider adolescence the appropriate moment to provide youth with sexuality education. If sexuality education (SE) has been a difficult domain to implement in school (Anastácio, 2007), it seems even more difficult in host institutions, or residence care, given the experiences of children and adolescents admitted, which often contain sensitive and problematic life stories in sexuality domain.

More, the professionals working with this population feel a lack of knowledge and skills to deal with the adolescents' sexual behaviors, which they face daily, as they have reported in several meetings we have had.

Given the problem faced, the institutionalization of children and adolescents due to negligence, maltreatment, school absenteeism and behavioural problems, including sexual risk behaviours, as well as the needs of caregivers who asked our support to better attend young people, we decide to start with a diagnostic of the adolescents' needs and conceptions about sexuality.

A previous research about the identification of adolescents' needs and conceptions of sexuality and teachers' needs to approach it in school was already done, with a sample of 397 students aged between 10 and 18 years old (Anastácio \& Marinho, 2014). Now, the focus of this study is on a specific group of adolescents, which also attend school and have similar ages, but are living in residence care conditions. And it is intended to verify if they have similar or different conception and interests compared with those living in family context.

\section{RESEARCH QUESTION AND OBJECTIVES}

In order to get a response for the problem, the following research question was formulated: What interests and curiosities of sexuality do adolescents living in residence care have?

In the same way, the main aim of this research was to make a diagnostic of adolescents' interests, needs and conceptions about sexuality. More specific objectives were to characterize the adolescents based on sociodemographic factors; to identify their conceptions about the role of SE, interveners in their SE and sources of information; to know what they want to learn more concerned with sexuality; and to establish associations between individual factors and adolescents' conceptions about sexuality.

\section{SAMPLE AND PARTICIPANTS}

The study included a convenience sample, as it was composed by adolescents living in residences care, with which we were collaborating and supporting them. The participants were from 8 residences care in northern region of Portugal. The sample included 114 adolescents aged between 11 to 21 years old (mean age $=15.67 \pm 2.41$ ), being 68 females and 46 males, and $60.5 \%$ of them living in residence care for more than 24 months.

\section{METHODOLOGY}

It was a cross-sectional study following a quantitative methodology. The tool for data collection was a questionnaire carried out and validated (through a pilot study with a similar little sample) exclusively for the propose of this research. Some questions were related to individuals' sociodemographic and considered independent variables or factors, namely gender, age, school grade and time living in residence care. The dependent variables selected for this paper are: i) perceptions about the role of SE in children and adolescents' development; ii) people that adolescents consider responsible for their SE; iii) sources of information about SE; iv) sexuality topics about which adolescents want to learn more.

The questionnaire was applied in the residences care by the professionals working with the adolescents, after the instructions given by the researcher. Before the application of the questionnaire, a protocol had been established between each institution and our research centre, and signed by the respective directors, as it was part of a whole research project funded by the Portuguese foundation for science and technology (FCT). All ethical procedures were fulfilled, the professionals responsible for the young people read and approved the questionnaire 


\section{CONCEPTIONS OF SEXUALITY OF ADOLESCENTS LIVING IN RESIDENCE CARES: ARE THEIR INTERESTS AND CURIOSITIES DIFFERENT?}

before their application and gave their consent. Teenagers were informed and participated voluntarily, filling in the in paper questionnaire. Everyone was guaranteed anonymity.

With the data collected by questionnaire a database was carried out in the SPSS software (version 27.0) and a statistical analysis was done. Starting with a descriptive analysis of each variable (independent and dependent), after an inferential analysis was done in order to associate the individual factors with the dependent variables and to verify their influence in adolescents' conceptions. When independent variables originated two groups the T-test was applied. In the cases of three or more groups non-parametric Kruskal-Wallis and Mann-Whitney tests were applied, given the characteristics of our sample.

\section{RESULTS}

Beginning by the socio demographic characterization, in this sample of 114 adolescents, 68 of them were girls and 46 boys. About the age, the youngers were 11 years old ( $n=6$ teens) and the older were $21(n=3)$, being the more frequent ages $14(n=12), 15(n=21), 16(n=19)$ and $17(n=17)$. About the school grade, we had teens from the $4^{\text {th }}$ grade (only one) to high school (only two), being the more frequent the $9^{\text {th }}$ grade $(n=30)$, followed by the $8^{\text {th }}$ and $6^{\text {th }}$ grade $(n=18)$ and $12^{\text {th }}$ grade $(n=14)$. The residence area they were come from were urban for 55 , rural for 42 and periurban for 15 . Concerning the period they were living in the institution, we found that the majority of the adolescents were living there more than 24 month ago $(n=69)$. Also 15 were there between 7 to 12 months and 14 between 13 to 24 months.

\section{Perceptions about the role of SE in children and adolescents' development}

Descriptive analysis can show us that in adolescents' opinion sexuality education contributes essentially to respect the different sexual orientations, to understand that sexuality is experienced differently throughout the lifespan and to promote gender equality of rights and opportunities between women and men. They do not agree very much that sexuality education awakens sexual behaviour prematurely and contributes do reduce violence in relationships (Figure 1).

Figure 1. Frequencies (F) for adolescents' perceptions about the role of sexuality education. (Source: Author)

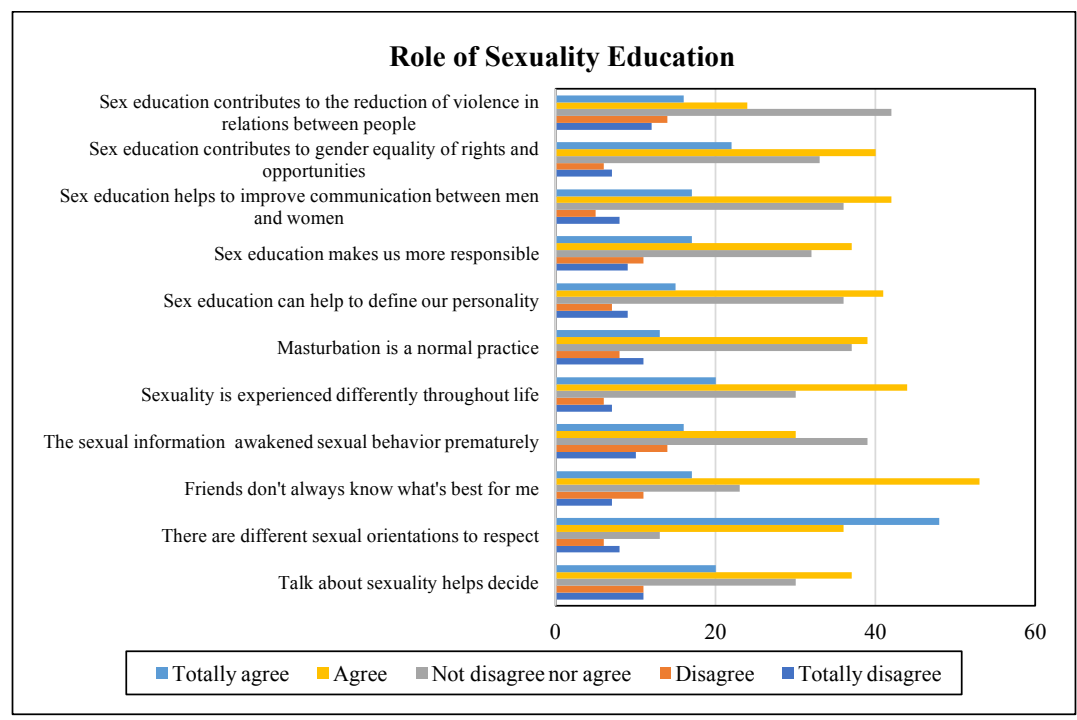


When testing the influence of individual factors in these conceptions, we found significant differences between sexes in the items: Talk about sexuality helps to decide $(t=2.057 ; p=.042)$, where girls agree more than boy with this sentence; Masturbation is a normal practice ( $\mathrm{t}=-2.556 ; \mathrm{p}=.012)$, with boys agreeing more than girls. The age also reveals some influence in the item Talk about sexuality helps to decide, having the teens with 19 years the high average order, differing significantly from those of $11(Z=-2.513 ; p=.014)$ and of 12 years old ( $Z=-$ 2.230; $p=.035$ ). The independent variables school grade, milieu of residence and time of institutionalization had not influence in these conceptions.

\section{Responsible for adolescents' Sexuality Education}

In relation to the people that adolescents consider responsible for their SE (Figure 2), physician obtained the first position, followed by nurse in second and mother in the third place. After these the staff of the institution include the preferred interveners comparing to those with whom the teenagers contact daily (teachers, school psychologist, friends, and soon).

Figure 2. Frequencies (F) for adolescents' conceptions about the responsible for sexuality education. (Source: Author)

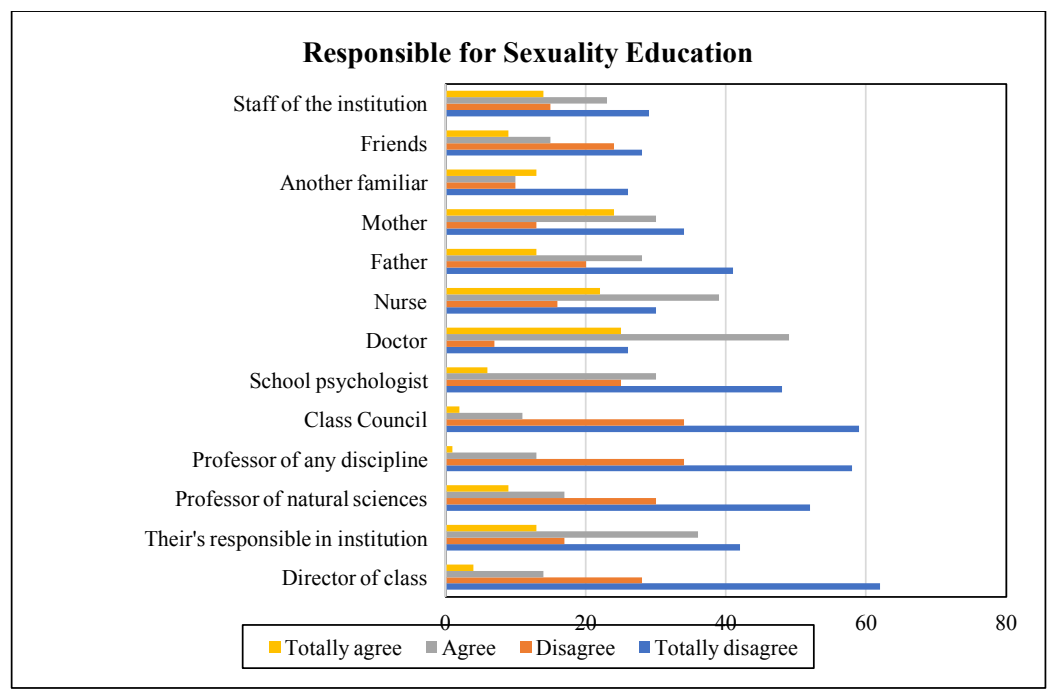

The individual factors that reveal some influence in adolescents' conceptions about the responsible for their sexuality education were sexes and milieu of residence. T-test shows significant differences between sexes for Doctor ( $\mathrm{t}=2.257 ; \mathrm{p}=.027)$ and Nurse $(\mathrm{t}=2.414 ; \mathrm{p}=.017)$, having girls higher preference for them than boys. Applying the Kruskal-Wallis test, significant differences were established by the independent variable milieu of residence for the intervener Class Council $(H=6.724 ; p=.035)$. The respective Mann-Whitney test clarify this difference between the adolescents from urban area and those from periurban area $(Z=-2.433 ; p=.015)$. These two groups of teens also differ for the intervention of the Teacher of natural sciences $(Z=-2.077 ; p=.038)$ and the School psychologist $(Z=-2.027 ; p=.043)$. Adolescents from urban area reveal the higher value of agreement with all these interveners. 


\section{CONCEPTIONS OF SEXUALITY OF ADOLESCENTS LIVING IN RESIDENCE CARES: ARE THEIR INTERESTS AND CURIOSITIES DIFFERENT?}

\section{Sources of information about SE}

With regard to sources of information, we can see in figure 3 that, in general, teens rarely search for information in the diverse sources and the father tends to be the last source of information to which they resort. Even so, the sources that they use most often are friends, internet, other relatives with approximate age, followed by health professionals and mother.

Figure 3. Frequencies for Adolescents' Sources of Information about Sexuality. (Source: Author)

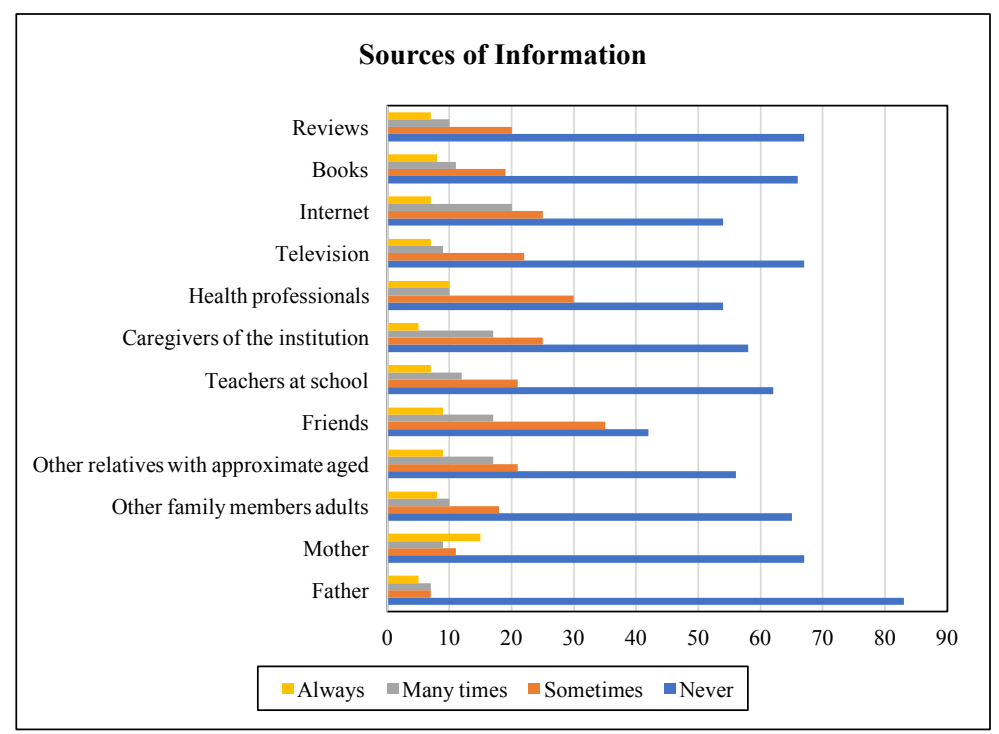

Verifying differences between sexes, significant statistical differences were found for teachers at school ( $\mathrm{t}=-$ 2.025; $p=.047$ ), having males higher mean value than females.

\section{Sexuality topics about which adolescents want to learn more}

The topics related to sexuality about which adolescents want to learn more (Figure 4) are Love, friendship and romantic relationships; Adolescence; Diversity, tolerance, sexual orientation and respect, Diseases and infections sexually transmitted; Notion of body and body image. On the other hand, topics in which they have less interest are those related to pleasure and intercourse, namely Sexual response and pleasure; Sexual desire; Masturbation; Relationships between peers; Maltreatment, harassment and sexual abuse; and Intercourse. 
Figure 4. Frequencies (F) for sexuality topics about which adolescents want to learn. (Source: Author)

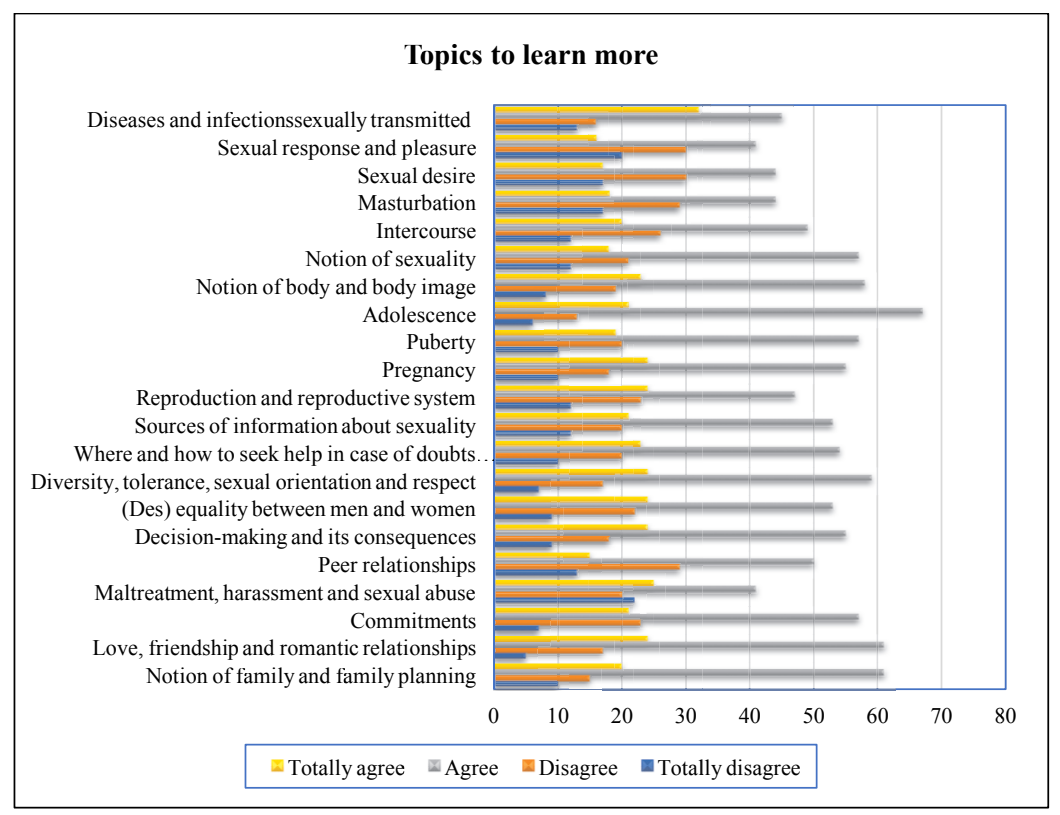

In the twenty one topics included in this scale, girls only obtain higher average value than boys in pregnancy; maltreatment, harassment and sexual abuse; love, friendship and romantic relationships; and in notion of family and family planning. Applying the t-test, significant differences between sexes were found only for the topic Notion of body and body image ( $\mathrm{t}=-3.175 ; \mathrm{p}=.002)$, in which girls show less interest than boys. No more individual factors reveal influence in teens' interests of learning concerned with sexuality.

\section{DISCUSSION}

Adding the life problematic experiences of the adolescents moved to residence care with their pubertal and socioemotional development, we are facing a very sensitive issue concerning adolescents' sexuality. Nevertheless, little differences were founded compared with adolescents living with their family.

The main role of SE is to help them to respect different sexual orientations, to understand that sexuality expresses differently along the lifespan, to promote equal rights and opportunities between men and women. These adolescents showed to be more favorable to the role of sex education than those studied by Anastácio and Marinho (2014) in schools.

The persons they more consider to be responsible for their SE are physician, nurse and mother, with significant differences for the health professionals. Curiously, instead of being out of family, for these adolescents, mother continues to be in third place of the preferred intervener in their sexuality education, likely founded in the previous study done by Anastácio and Marinho (2014) in schools.

Concerning with the sources of sexuality information, internet, friends and mother are repeatedly the more frequent. This result is in coherent with those about the responsible person for SE, since mother continues between the first three persons.

The topics that adolescents prefer to learn more are those related to sexually transmissible infections and dis- 


\section{CONCEPTIONS OF SEXUALITY OF ADOLESCENTS LIVING IN RESIDENCE CARES: ARE THEIR INTERESTS AND CURIOSITIES DIFFERENT?}

eases, their own development, relationships and family planning. The less important themes for them are those about sexual desire and activities (positives and negatives). Nevertheless, boys continue more interested in topics concerned with pleasure, which is similar to the results of the sample we studied in schools (Anastácio \& Marinho, 2014).

Our concern with sexual health of young people living in residence care also deserved the attention of the Child Development and Successful Youth Transitions Committee (CDSYTC) of the California Child Welfare Council, in 2015, establishing a workgroup to promote healthy sexual development of institutionalized youth, given the lack of policies and practices in this domain. After discussion including institutionalized youth in the group, many topics were identified and, more precisely about sex, dating and masturbation, the lack of opportunities to talk about intimate relationships, safe sex practices and how teens can communicate with others about their needs were referred. Concerning with the caregivers, they identified their "need for more information on how to respond to youth's questions and behaviors relating to sexual curiosity" (CDSYTC, 2015: 2).

\section{CONCLUSIONS AND RECOMMENDATIONS}

There are little differences in sexuality interests for adolescents living in foster care homes comparing to those living in their original families, namely, they are more favorable to sexuality education than the adolescents of our previous study in schools (Anastácio \& Marinho, 2014).

The conceptions and interests about sexuality of adolescents living in residence care are similar to those living in their original family environment. Despite being taken from the family, they also continue to dream with a family and want to know more about family notion and planning. This result can reflect a basic need of all human beings, that is living in a family with care, affection and love.

The knowledge of teens' interests should be the starting point for sexuality education in these institutions. And an important idea is confirmed: adolescents living in institutionalization context are more equal than different and deserve all rights to have a comprehensive sexuality education.

\section{FUNDING}

This work was financially supported by Portuguese national funds through the FCT (Foundation for Science and Technology) within the framework of the CIEC (Research Center for Child Studies of the University of Minho) project under the reference UIDB/00317/2020.

\section{BIBLIOGRAPHIC REFERENCES}

Anastácio, Z. (2007). Educação Sexual no 1.․ㅡ CEB: Concepções, Obstáculos e Argumentos dos Professores para a sua (não) Consecução. Tese de Doutoramento, Universidade do Minho e Universidade Claude Bernard Lyon-1

Anastácio, Z. \& Marinho, S. (2014). Results of a sex education program for 2nd and 3rd cycle of Portuguese basic education students. International Journal of Developmental and Educational Psychology. INFAD Revista de Psicología, N. ․ 1-Vol.3, 2014, pp. 423-430

California Child Welfare Council, Child Development and Successful Youth Transitions Committee (2015). Supporting Health Sexual Development of Youth in Foster Care - summary of findings and recommendations. California: California Child Welfare Council. [Access:

http://www.chhs.ca.gov/Pages/CAChildWelfareCouncil.aspx ]

Christie, D., \& Viner, R. (2005). Adolescent development. BMJ (Clinical research ed.), 330(7486), 301-304. https://doi.org/10.1136/bmj.330.7486.301

Macedo, D., Silva, P. \& Banhudo, S. (2020). CASA 2019 - Relatório de Caracterização Anual da Situação de Acolhimento das Crianças e Jovens. Instituto de Segurança Social, I.P. (Available in: https://www.segsocial.pt/documents/10152/13200/Relat\%C3\%B3rio+CASA+2019/0bf7ca2b-d8a9-44d2-bff7df1f111dc7ee ) 
Portugal, Diário da República Eletrónico, 1. a Série, n.ำ 206, Decreto-Lei n.ำ164/2019 de 25 de outubro, Estabelece o regime de execução do acolhimento residencial, medida de promoção dos direitos e de proteção das crianças e jovens em perigo, pp.65-79 (Available on: https://dre.pt/dre/detalhe/decreto-lei/164-2019125692191 ) 
